\title{
Implementation of Interactive Conceptual Instruction (ICI) Learning Model Assisted by Computer Simulation: \\ Impact of Students' Conceptual Changes on Force and Vibration
}

\author{
https://doi.org/10.3991/ijet.v16i22.25465
}

\author{
Ida Kaniawati, Widyatami Nurul Maulidina, Hera Novia, Iyon Suyana \\ Achmad Samsudin, Adam Hadiana Aminudin, Endi Suhendi ${ }^{(\bowtie)}$ \\ Universitas Pendidikan Indonesia, Bandung, Indonesia \\ endis@upi . edu
}

\begin{abstract}
This study aims to examine the implementation of the Interactive Conceptual Instruction (ICI) learning model assisted by computer simulation to change students' conception of force and vibration. However, the change in the conception of the research is focused on the Misconception category (MC) because it is fundamental in the learning of physics. This study used a mixedmethod design with an exploratory sequence. It was conducted on 30 students of Class $\mathrm{X}$ in one of the high schools in Cimahi city. The instrument used comprised 20 questions in a four-tier test. The analysis was conducted using a combination of two methods to analyze: (1) the changes in the conception based on three categories of conception, in exchange for the three categories of misconceptions (Acceptable Change (MC-PU and MC-SU), Not Acceptable (MC-NU and the MC-NC), and No Change (MC-MC), (2) the calculations of percentage for each change in the conceptions that occurred. The results showed that changes could be identified from the following categories of misconceptions: Acceptable Change (AC) categories (including MC-PU (63\%) and MC-SU (53\%), No Change (NCh) category (MC-MC (63\%)), and Not Acceptable (NA) categories (include MC-NU (40\%) and MC-NC (3\%)). Thus, the ICI learning model, assisted by computer simulation, can change students' misconceptions and improve their concept of force and vibration.
\end{abstract}

Keywords - conceptual changes, Interactive Conceptual Instruction (ICI)

learning model, computer simulation

\section{Introduction}

Understanding is the process of blending and linking various types of relevant information. The comprehension procedure is a structure input procedure performed by the student. Conceptual Understanding allows students to relate ideas and show relationships and complementarities between many concepts [1-3]. Overall, students can apply concepts to multiple conditions, explain conditions or concepts through philanthropic 
logical motifs, express concepts in numerous actions. This makes understanding a concept that is fundamental in learning something. If a concept can be understood correctly, the understanding follows the scientific conception. However, if it is not following the scientific concept (according to the agreement of the experts), then it becomes a misconception. Misconceptions can be interpreted as notions, main ideas, and views of a person's concept that do not follow the correct concept approved by experts [4-6]. Misconceptions are widespread among students in various fields. One of them is the misconception of physics concepts.

Several studies show that students still have misconceptions about some concepts in physics. For example, in mechanics [7-8] momentum [9], electricity and magnetism [10-12] thermodynamics [13], modern Physics [14], optics [15-16], vibrations and waves [17], work and energy [18-19], and lightwave [20-21]. In addition, misconceptions also occur in the concept of force and vibration. Research conducted by [22] showed many misconceptions about the concept of simple harmonic vibrations. Hence, understanding the concept of simple harmonic vibrations is included in the low category. There are still many misconceptions about it. This is also supported by the preliminary studies that have been carried out.

Based on a preliminary study using the Force and Vibration diagnostic test in a twotier format, it was found that many students still experienced such misconceptions. The misconceptions that occurred included the concept of simple harmonic vibrations, initial deviation, restoring force, velocity, acceleration, period, and energy. Overall, $50.6 \%$ of the students experienced misconceptions. The most significant percentage of misconceptions involved the concept of acceleration and period in simple harmonic vibrations. As mentioned earlier, the high percentage of students' misconceptions of the Force and Vibration concept indicates the need for research to change student misconceptions.

Conceptual change is considered a change in students' mindset from one level of understanding to another. However, changing the conception is done to change students' understanding of a phenomenon for the better. According to [23], conceptual changes are significant in science education. Students often have misconceptions about their significance, movies, TV shows, and thinking about science. Furthermore, at least three conditions for a student's prior knowledge [24]: students have no ledge, incomplete knowledge, and conceptions contradict the concept of research objects. Based on this, learning is the addition of new knowledge of the first condition. It can fill the void of the second condition, but in the understanding edition, learning becomes. It can change. Thus, one of the efforts that can be done is to implement a learning model that can change students' misconceptions. To accomplish this, we used the Interactive Conceptual Instruction (ICI) model in this study.

Interactive Conceptual Instruction (ICI) is learning developed by [25]. ICI was designed to encourage conceptual coherence and is based on the premise that understanding physics requires an interactive process that allows for ideas to be expressed through thinking and conversation between teachers and students. In other words, the process must take place in the teaching and learning dialogue [25]. To facilitate conceptual change, ICI is based on the Conceptual Change Model (CCM). Four conditions that must be fulfilled for students to experience conceptual change include dissatisfaction 
with existing conceptions, the intelligibility of new concepts, plausibility to believe in new ideas, and fruitfulness, which need to be valuable in a pragmatic sense [26]. Those four conditions can be fulfilled by the ICI learning model [12]. In line with a claim made by [27], there is empirical evidence that Interactive Conceptual Instruction (ICI) can significantly improve students' conceptual understanding. The main components of ICI are focused on concept, use of text, research-based materials, and class interactions [28]. Therefore, ICI learning stages include conceptual focus, use of text, research-based material, and classroom instruction.

Furthermore, previous research showed that the ICI Learning model could effectively reduce student misconceptions [29-30]. These findings were achieved because the stages in the ICI learning model can support students to find the correct concept and change students' misconceptions. However, some things in physics are abstract. Thus, the media is needed as a facility in learning.

In learning, the media has an important role. During the Covid-19 pandemic, most learning has been diverted to online learning [31]. In addition, the use of media has been developed on various platforms, such as mobile, web apps, and computer simulations. Several studies revealed that mobile learning could be used as a medium for every student at various levels [32-34]. Research by [35] demonstrated that tablets could be one of the tools students use in learning compared to print media. In addition, the use of mobile learning is also used in various learning activities such as STEM [36], gamebased learning [37], and conceptual learning [38]. The advantage that can be derived from interactive media in learning (technology-based) is that teachers or students can access and evaluate any learning outcomes anywhere at any time [39].

However, in this study, we used interactive computer simulation to overcome these problems, considering it will be implemented in the classroom. Thus, that it can be more effective and fairer if used in groups. Technological devices in interactive computer simulations can promote students' and teachers' thinking skills, make multi-representations, communicate with each other, explore scientific phenomena, and carry out investigations to perform scientific studies [40]. This is following ICI learning to change students' misconceptions. Physical sensations can be represented in words, equations, animations, graphs, tables, pictures, or diagrams. Making connections between multiple representations is an essential ability to increase understanding of the whole concept. The simulation also provides a bridge between students' knowledge before and after learning Physics and helps students develop scientific awareness and reduce misconceptions or provide conceptual change [41]. The results of previous research generally showed that the use of interactive computer simulations in Physics learning contributed to positive results [42-44].

In this study, computer simulations were given to students, especially at the conceptual focus and research-based material stages. Thus, students can find it easier to carry out each step in the ICI learning model to get the correct conception in the Force and Vibration unit. The computer simulation that was used in this study used the Macromedia flash application. This computer simulation was designed based on the common misconceptions experienced by students in Force and Vibration unit. The example of a computer simulation display used in this study can be seen in Figure 1. 


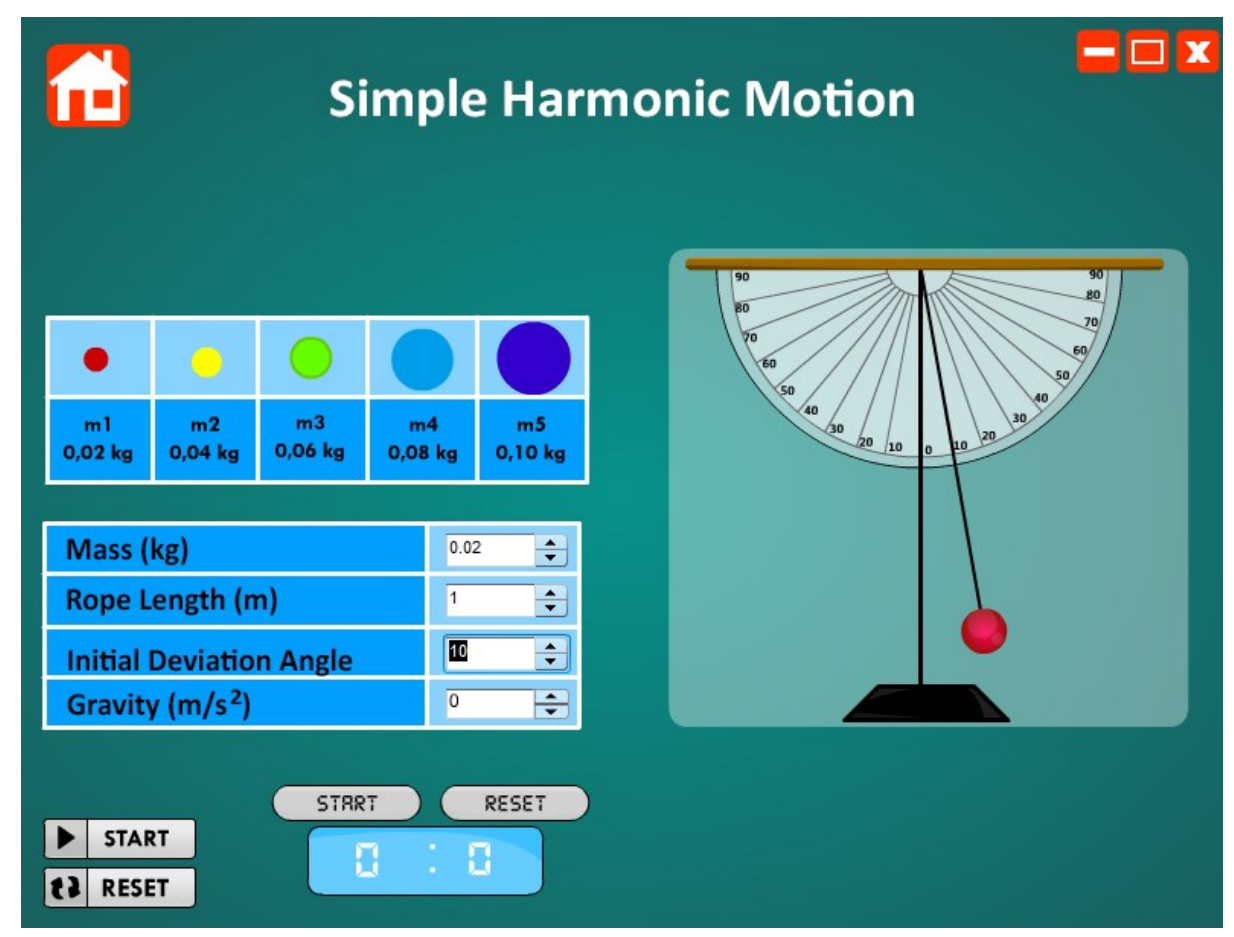

Fig. 1. The example of simulation display

The stages of Interactive Conceptual Instruction (ICI) Learning Model Assisted by Computer Simulation are as follows.

In the first stage (Conceptual Focus), the students are made aware of and dissatisfied with their initial conceptions. To achieve this, computer multimedia consisting of simulations and videos that show the Physics phenomena related to the Physics concepts to be discussed were delivered to students.

The second stage (Use of Text) aims to prepare students to see their dissatisfaction with the concepts and problems or misconceptions they are experiencing. To achieve this second stage, textbooks and other learning resources were used. According to [28], texts were used to find keywords related to concepts. The students were directed to read textual materials and then transform these materials into a concept map.

In the third stage (Research-Based Materials), the students were instructed to form groups of five to six to conduct experiments using computer simulations. Then the teacher guided the students to fill in the LKPD PDEODE*E. [12] developed the ICI model with the PDEODE*E task in the research-based material section. It was assessed that the PDEODE * E task-based teaching is more vital to support students' conceptual change, namely those who experience misconceptions. Therefore, the PDEODE * E task is suitable for using research-based material on the ICI model to optimize students' conceptual change. The PDEODE*E consists of seven elements: predict, discuss, explain, observe, discuss II, explore, and explain II. ICI learning model is assumed to be 
the "home" for the PDEODE*E task. Students can be actively involved in their conceptual change and develop their conceptual understanding.

The fourth stage (Classroom Interaction) was the last in ICI learning. Class interaction mentioned referred to the exchange that occurred in class in discussions between students and collaborative interactions between teachers and students. At this stage, the teacher guided the students' meetings in each group and helped the students to solve problems by comparing the results of exploration sheets from each group. The interaction was also carried out in the teacher's clarification when misconceptions could still be found at the end of the lesson. Therefore, this study aims to implement the Interactive Conceptual Instruction (ICI) learning model assisted by computer simulation to change the students' conception of force and vibration.

\section{Methods}

\subsection{Research design}

Mixed methods research was used in this study. This method combined qualitative and quantitative analyses by mixing the two methods [45-46]. The qualitative approach is used to describe the changes in students' conceptions after the implementation of computer-assisted ICI. In contrast, the quantitative method is used to calculate the percentage of the conceptual difference. The exploratory sequential mixed-method design process in this study is shown in Figure 2.

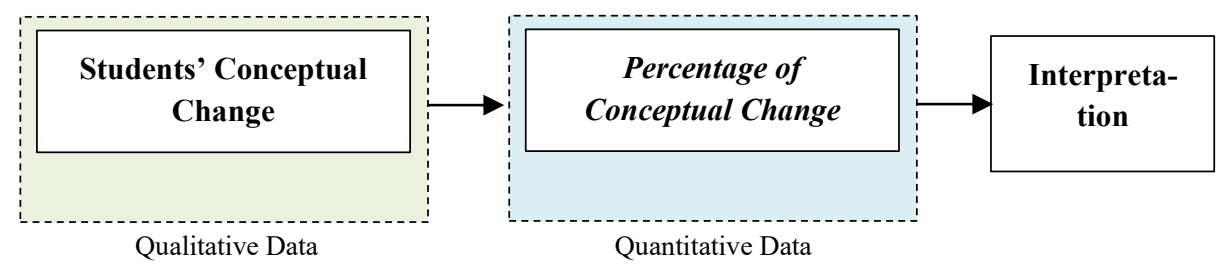

Fig. 2. The Process of Exploratory Sequential Mixed-Method Design

\subsection{Participants}

Cimahi City is one of the administrative cities in West Java, and its location is close to the capital city of West Java, namely Bandung. Participants in this study consisted of 30 students of Class $X$ in one of the high schools in Cimahi city. The area map of the participants can be seen in Figure 3. 


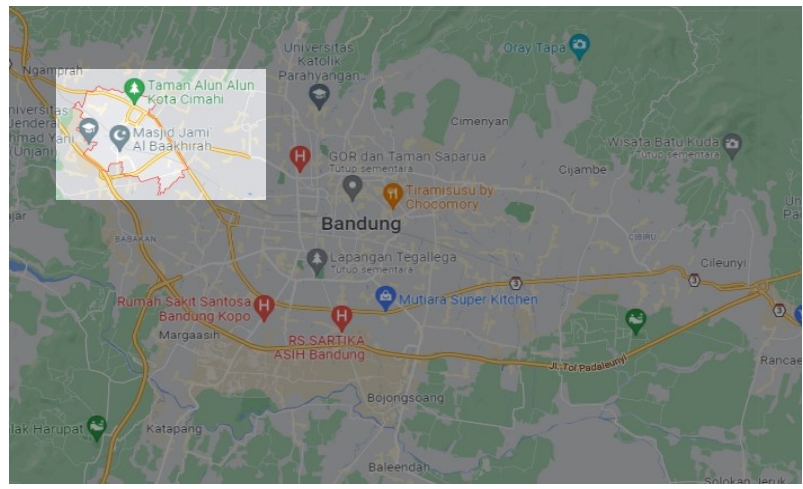

Fig. 3. The Map of Cimahi City (by Google Map)

\subsection{Instruments}

The diagnostic test instrument used is a four-tier test consisting of 20 items regarding the concepts of force and vibration. This instrument has a reliability index (KR-20) of 0.71 and was given to students during the pre-test and post-test. The results are then used to determine changes in the students' conceptions, viewed from the conception category at the pre-test and post-test. Thus, the aim of this research can be achieved. An example of the four-level test used is illustrated in Figure 4.

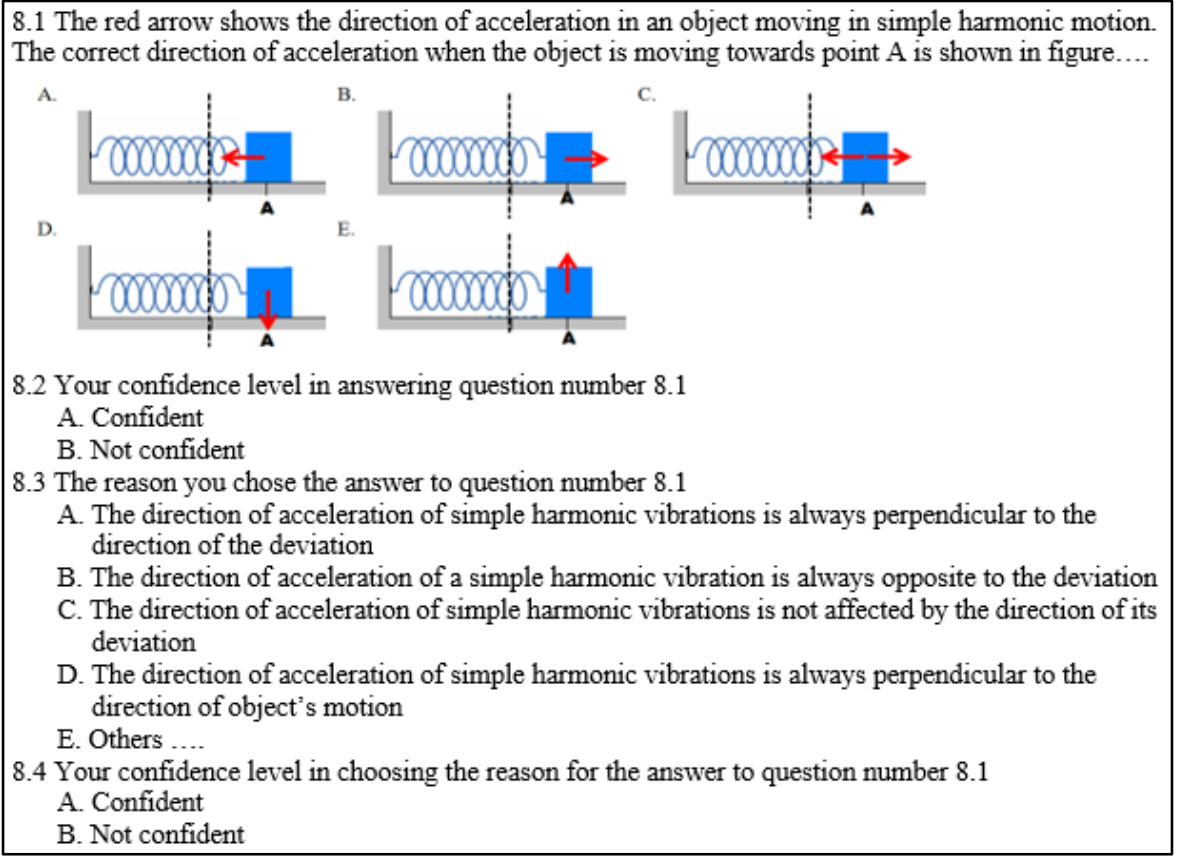

Fig. 4. The example of a four-tier test 
The tier-1 (8.1) contains multiple-choice conceptual questions with four trick options and one correct answer. Tier-2 (8.2) includes students' confidence level in answering the question in the previous class in the form of "Confident" and "Not Confident" options. Tier-3 (8.3) contains scientific reasoning of the question in level one in multiple choices options with four selectable reasonings and one open logic. Tier-4 (8.4) includes the confidence level for the reasons given at the third level in the form of "Confident" and "Not Confident" options. A student is considered a misconception when they answer the questions on Tier- 1 and Tier- 3 incorrectly. At the same time, they choose "Confident" on Tier-2 and Tier-4.

\subsection{Data analysis}

The analysis is conducted in two ways: (1) to analyze the conceptual changes based on three categories of conception, but this is accomplished for changes in the misconception categories only, and (2) Calculations of the percentage for each change in conception occurs.

Conceptual Changes Analysis (qualitative). Conceptual change analysis is carried out by entering each student's answer in five categories of conception, as shown in Table 1 .

Table 1. Conception Category

\begin{tabular}{|l|c|}
\hline Conception Category & Score \\
\hline Sound Understanding (SU) & 2 \\
\hline Partial Understanding (PU) & 1 \\
\hline Misconceptions (MC) & 0 \\
\hline No Understanding (NU) & 0 \\
\hline No Coding (NC) & 0 \\
\hline
\end{tabular}

Furthermore, the pre-test and post-test data are identified based on the changes in conception that occurred. Twenty-four possible changes in concept can occur (Table 2). However, all these possibilities have been included in three categories of conceptual change, including Acceptable Change (AC), Not Acceptable (NA), and No Change (NCh) [12].

However, of the 24 possibilities available, only five options will be used because the focus of this study is on the category of misconceptions. Thus, the changes that will be identified are only changes for the variety of misconceptions (Figure 5). 
Paper-Implementation of Interactive Conceptual Instruction (ICI) Learning Model Assisted by...

Table 2. Possible Conceptual Change

\begin{tabular}{|c|c|c|c|c|}
\hline No & Pre-Test & Change $(\rightarrow)$ & Post-Test & Category \\
\hline 1 & $\mathrm{MC}$ & $\rightarrow$ & $\mathrm{PU}$ & \multirow{7}{*}{ Acceptable Change (AC) } \\
\hline 2 & $\mathrm{MC}$ & $\rightarrow$ & SU & \\
\hline 3 & $\mathrm{NU}$ & $\rightarrow$ & $\mathrm{PU}$ & \\
\hline 4 & NU & $\rightarrow$ & SU & \\
\hline 5 & $\mathrm{PU}$ & $\rightarrow$ & $\mathrm{SU}$ & \\
\hline 6 & $\mathrm{NC}$ & $\rightarrow$ & $\mathrm{PU}$ & \\
\hline 7 & $\mathrm{NC}$ & $\rightarrow$ & SU & \\
\hline 8 & $\mathrm{MC}$ & $\rightarrow$ & $\mathrm{NU}$ & \multirow{12}{*}{ Not Acceptable (NA) } \\
\hline 9 & NU & $\rightarrow$ & $\mathrm{MC}$ & \\
\hline 10 & $\mathrm{PU}$ & $\rightarrow$ & $\mathrm{MC}$ & \\
\hline 11 & $\mathrm{PU}$ & $\rightarrow$ & $\mathrm{NU}$ & \\
\hline 12 & SU & $\rightarrow$ & $\mathrm{PU}$ & \\
\hline 13 & SU & $\rightarrow$ & $\mathrm{NU}$ & \\
\hline 14 & $\mathrm{SU}$ & $\rightarrow$ & $\mathrm{MC}$ & \\
\hline 15 & $\mathrm{PU}$ & $\rightarrow$ & $\mathrm{NC}$ & \\
\hline 16 & $\mathrm{MC}$ & $\rightarrow$ & $\mathrm{NC}$ & \\
\hline 17 & $\mathrm{NC}$ & $\rightarrow$ & $\mathrm{MC}$ & \\
\hline 18 & $\mathrm{NU}$ & $\rightarrow$ & $\mathrm{NC}$ & \\
\hline 19 & $\mathrm{NC}$ & $\rightarrow$ & $\mathrm{NU}$ & \\
\hline 20 & $\mathrm{PU}$ & $\rightarrow$ & $\mathrm{PU}$ & \multirow{5}{*}{ No Change (NCh) } \\
\hline 21 & $\mathrm{NU}$ & $\rightarrow$ & $\mathrm{NU}$ & \\
\hline 22 & $\mathrm{MC}$ & $\rightarrow$ & $\mathrm{MC}$ & \\
\hline 23 & SU & $\rightarrow$ & $\mathrm{SU}$ & \\
\hline 24 & $\mathrm{NC}$ & $\rightarrow$ & $\mathrm{NC}$ & \\
\hline
\end{tabular}

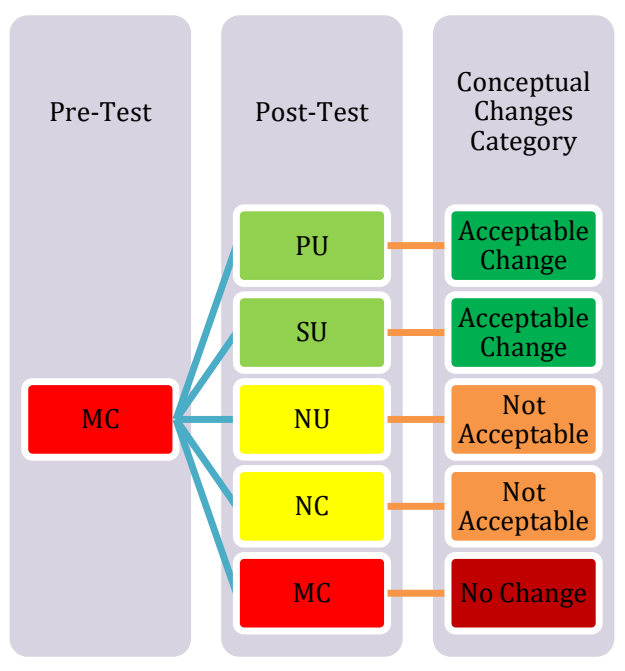

Fig. 5. Possible Changes in the Misconception Category 
Percentage of Conceptual Change (quantitative). The calculations of students' conceptions of each item in the experimental and control classes in pre-test and posttest can be presented in percentages using the following equation.

$$
(\%)=\frac{\sum \text { students } \text { who experience changes in conception }}{\sum \text { students }} \times 100
$$

These results are then interpreted using a Radar Chart to describe any changes in the conception that occurs.

\section{$3 \quad$ Result and discussion}

Based on the results of calculations for the five categories of student conceptions, namely Sound Understanding (SU), Partial Understanding (PU), No Understanding (NU), Misconception (MC), and No Coding (NC) [12], Table 3 presents the data for the conception category of the students during the pre-test and post-test.

Table 3. Categories of students' conceptions

\begin{tabular}{|c|c|c|c|c|c|c|c|c|c|c|}
\hline \multirow{3}{*}{$\begin{array}{l}\text { Question } \\
\text { Number }\end{array}$} & \multicolumn{10}{|c|}{ Conception Criteria } \\
\hline & \multicolumn{2}{|c|}{$M C$} & \multicolumn{2}{|c|}{$S U$} & \multicolumn{2}{|c|}{$P U$} & \multicolumn{2}{|c|}{$N U$} & \multicolumn{2}{|c|}{$N C$} \\
\hline & $\begin{array}{l}\text { Pre- } \\
\text { (\%) }\end{array}$ & $\begin{array}{l}\text { Post- } \\
\text { (\%) }\end{array}$ & $\begin{array}{c}\text { Pre- } \\
\text { (\%) }\end{array}$ & $\begin{array}{c}\text { Post- } \\
\text { (\%) }\end{array}$ & $\begin{array}{l}\text { Pre- } \\
\text { (\%) }\end{array}$ & $\begin{array}{l}\text { Post- } \\
\text { (\%) }\end{array}$ & $\begin{array}{l}\text { Pre- } \\
\text { (\%) }\end{array}$ & $\begin{array}{l}\text { Post- } \\
\text { (\%) }\end{array}$ & $\begin{array}{c}\text { Pre- } \\
\text { (\%) }\end{array}$ & $\begin{array}{c}\text { Post- } \\
\text { (\%) }\end{array}$ \\
\hline 1 & 26.7 & 13.3 & 36.7 & 26.7 & 20.0 & 53.3 & 16.7 & 6.7 & 0.0 & 0.0 \\
\hline 2 & 6.7 & 3.3 & 26.7 & 43.3 & 46.7 & 36.7 & 20.0 & 16.7 & 0.0 & 0.0 \\
\hline 3 & 20.0 & 13.3 & 0.0 & 13.3 & 33.3 & 46.7 & 46.7 & 26.7 & 0.0 & 0.0 \\
\hline 4 & 63.3 & 56.7 & 0.0 & 0.0 & 10.0 & 20.0 & 26.7 & 20.0 & 0.0 & 3.3 \\
\hline 5 & 13.3 & 0.0 & 10.0 & 70.0 & 53.3 & 30.0 & 23.3 & 0.0 & 0.0 & 0.0 \\
\hline 6 & 30.0 & 26.7 & 6.7 & 0.0 & 26.7 & 56.7 & 33.3 & 16.7 & 3.3 & 0.0 \\
\hline 7 & 30.0 & 26.7 & 6.7 & 36.7 & 36.7 & 30.0 & 26.7 & 6.7 & 0.0 & 0.0 \\
\hline 8 & 23.3 & 20.0 & 0.0 & 16.7 & 50.0 & 56.7 & 26.7 & 6.7 & 0.0 & 0.0 \\
\hline 9 & 16.7 & 16.7 & 0.0 & 26.7 & 66.7 & 46.7 & 16.7 & 10.0 & 0.0 & 0.0 \\
\hline 10 & 23.3 & 3.3 & 6.7 & 10.0 & 53.3 & 76.7 & 16.7 & 10.0 & 0.0 & 0.0 \\
\hline 11 & 26.7 & 20.0 & 3.3 & 26.7 & 33.3 & 36.7 & 33.3 & 16.7 & 3.3 & 0.0 \\
\hline 12 & 36.7 & 26.7 & 3.3 & 36.7 & 30.0 & 16.7 & 26.7 & 16.7 & 3.3 & 3.3 \\
\hline 13 & 30.0 & 13.3 & 3.3 & 50.0 & 40.0 & 23.3 & 23.3 & 6.7 & 3.3 & 6.7 \\
\hline 14 & 23.3 & 6.7 & 3.3 & 30.0 & 60.0 & 63.3 & 6.7 & 0.0 & 6.7 & 0.0 \\
\hline 15 & 30.0 & 16.7 & 0.0 & 10.0 & 43.3 & 53.3 & 23.3 & 20.0 & 3.3 & 0.0 \\
\hline 16 & 30.0 & 13.3 & 0.0 & 3.3 & 30.0 & 73.3 & 33.3 & 10.0 & 6.7 & 0.0 \\
\hline 17 & 30.0 & 16.7 & 0.0 & 23.3 & 26.7 & 46.7 & 40.0 & 13.3 & 3.3 & 0.0 \\
\hline 18 & 36.7 & 23.3 & 0.0 & 10.0 & 26.7 & 46.7 & 33.3 & 20.0 & 3.3 & 0.0 \\
\hline 19 & 26.7 & 26.7 & 6.7 & 10.0 & 16.7 & 43.3 & 43.3 & 20.0 & 6.7 & 0.0 \\
\hline 20 & 23.3 & 16.7 & 0.0 & 26.7 & 33.3 & 50.0 & 36.7 & 6.7 & 6.7 & 0.0 \\
\hline Average & 27.3 & 18.0 & 5.7 & 23.5 & 36.8 & 45.3 & 27.7 & 12.5 & 2.5 & 0.7 \\
\hline
\end{tabular}

$\mathrm{MC}=$ Misconception; $\mathrm{SU}=$ Sounds Understanding; $\mathrm{PU}=$ Partial Understanding; NU=Not Understanding; $\mathrm{NC}=$ No Code. 
Based on Table 3, it is apparent that the number of students who experience misconceptions tends to decrease from pre-test to post-test. The reduction in the number of students who participate misconceptions mainly occurs in Question 10, namely the misunderstanding about the following statement "The acceleration of the object at any point in simple harmonic vibrations are the same." The reduction in the percentage of students who experience misconceptions in Question 10 reaches 20\%. The decrease in the rate of students who participate misconceptions about Question 10 is also followed by an increase in the number of students who understand the concept (SU), by $3.3 \%$, and partially understand (PU) by $23.3 \%$. In general, the level of conception of students before and after participating in ICI learning assisted by computer simulations is presented in Figure 6.

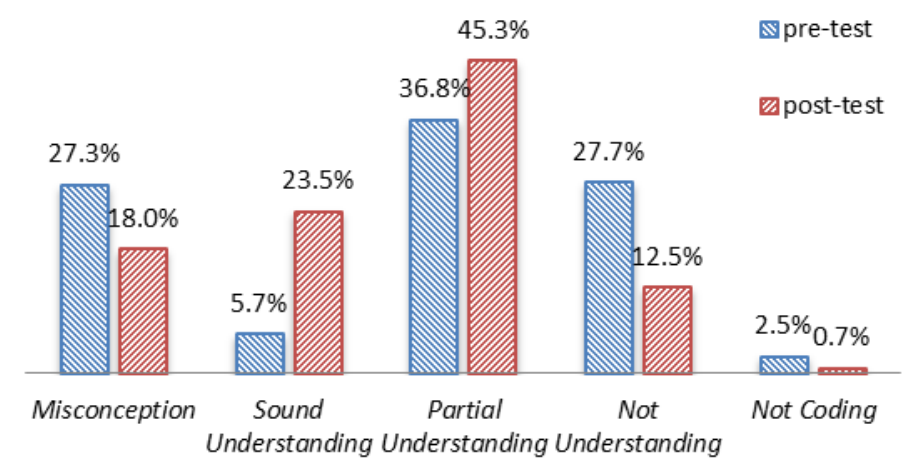

Fig. 6. The percentage of students' conceptual criteria before and after the treatment

Although most students who experience misconceptions decrease from the pre-test to the post-test, it is still found that the number of misconceptions does not change from the pre-test to the post-test in some cases. For example, it is shown in Question 19, which is a misconception of the following statement "The total energy in simple harmonic vibrations is affected by the object's mass." The percentage of students who experience misunderstandings does not change from the pre-test to the post-test, $26.7 \%$. This indicates that the application of ICI assisted by computer simulations cannot entirely reduce the students' misconceptions. This can be caused by several factors, including the implementation of ICI learning aided by computer simulations which will be explained in the following discussion, which can also be caused by the limitations of researchers in controlling students' psychological problems. This is in line with the findings [12], which states that misconceptions in students are difficult to change because of the limitations of researchers in controlling psychological problems such as their way of thinking, their teamwork skills in groups, and their motivation. In addition, misconceptions are difficult to change because students maintain their initial concepts following the statement [12], which states that changing student conceptions takes a long time because misconceptions are embedded in their minds. Misconceptions have the following character: challenging to change, stable, and well embedded in the cognitive realm of students [42]. 
Furthermore, after the implementation of Interactive Conceptual Instruction (ICI) learning assisted by computer simulations, the students' conceptual changes can be categorized into three categories, which are Acceptable Change (AC), Not Acceptable (NA), and No Change (NCh). The types of conceptual changes that occurred are shown in Table 4.

Table 4. Categories of students' conceptual changes

\begin{tabular}{|c|c|c|c|c|c|c|}
\hline $\begin{array}{l}\text { Changes } \\
\text { Category }\end{array}$ & No & $\begin{array}{c}\text { Pre- } \\
\text { test }\end{array}$ & $\begin{array}{c}\text { Post- } \\
\text { test }\end{array}$ & Student's Code (Question Number) & f & $\%$ \\
\hline \multirow{7}{*}{$\begin{array}{l}\text { Acceptable } \\
\text { Change } \\
\text { (AC) }\end{array}$} & 1 & $\mathrm{MC}$ & PU & $\begin{array}{c}\text { S1(4,10,15,16,17,18,19); S2(1,2,19); S3(1,19); S4(4,9,14,19,20); } \\
\text { S5(1,6,7,10,14,15,16,17,19); S6(3,6,10); S7 }(10,15,18,19) ; \\
\text { S8(8,10,17); S9(7,10,12,18,20); S10(4,11,18,20); S12(11,12,13); } \\
\text { S13(1,8,16,17); S20(12); S22(15,20); S23(13); S24(2,3,18); } \\
\text { S25(6,13,14,18,20); S26(8); S30 }(1,4,9)\end{array}$ & 19 & 63 \\
\hline & 2 & $\mathrm{MC}$ & SU & $\begin{array}{c}\text { S1(1,5,8,9,13,20); S4(18); S6(7); S7(3,5,7,9,11,14,17); } \\
\text { S8(1,5,12,15,18); S9(14,17); S10(13); S11(9); S12(5,7,15); } \\
\text { S13(13); S14(11); S16(7); S17(11); S22(14); S24(10,12,13,14,17); } \\
\text { S25(19) }\end{array}$ & 16 & 53 \\
\hline & 3 & NU & PU & $\begin{array}{l}\text { S2(6,10,14); S3(6,11,17,20); S4(2,5,6); S6(9,14); S10(8); } \\
\text { S11(6,10,16,17,19); S13(3,6); S14(2,8,20); S15(3,11,12,15,17); } \\
\text { S16(8,11,16); S17(3,16); S18(3,15,20); S19(6,7,8,15,16,20); } \\
\text { S20(10,16,178,18); S21(3,5,20); S22(8,11); S23(15,19); } \\
\text { S24(6,20); S26(11,16,17,18,19); S27(4,8,13,16,17,18); } \\
\text { S28(9,10,16,18); S29(1,20); S30(10) }\end{array}$ & 23 & 77 \\
\hline & 4 & $\mathrm{NU}$ & SU & $\begin{array}{c}\mathrm{S} 2(13) ; \mathrm{S} 3(7,13) ; \mathrm{S} 6(5,8,11,20) ; \mathrm{S} 10(2) ; \mathrm{S} 11(7) ; \mathrm{S} 15(16) ; \\
\mathrm{S} 17(8,17) ; \mathrm{S} 18(5) ; \mathrm{S} 19(5,11) ; \mathrm{S} 21(12) ; \mathrm{S} 22(1,7) ; \mathrm{S} 23(2,3,13,17) ; \\
\mathrm{S} 24(5,7) ; \mathrm{S} 27(12) ; \mathrm{S} 28(13) ; \mathrm{S} 29(5,7,12) ;\end{array}$ & 16 & 53 \\
\hline & 5 & PU & SU & $\begin{array}{c}\text { S1(12,14); S2(9); S3(9); S5(9); S6(12,13); S7(2,812,20); } \\
\text { S8(13,14,20); S9(3,5,11,15,19); S11(2,5,13,20); S14(5,9,13,18); } \\
\text { S15(5,9,18) S16(2,5,10); S17(2,5); S19(2,3,17); S20(20); } \\
\text { S22(10,12); S23(5,7,8,11,12); S24(8); S25(9); 26(13,14); } \\
\text { S28(2,5,20); S29(14); S30(5) }\end{array}$ & 23 & 77 \\
\hline & 6 & $\mathrm{NC}$ & PU & S18(16); S21(14); S30(14,15,16,17,19,19) & 3 & 10 \\
\hline & 7 & $\mathrm{NC}$ & SU & $\mathrm{S} 27(20) ; \mathrm{S} 30(11,12)$ & 2 & 7 \\
\hline \multirow{8}{*}{$\begin{array}{l}\text { Not } \\
\text { Acceptable } \\
\text { (NA) }\end{array}$} & 8 & $\mathrm{MC}$ & NU & $\begin{array}{c}\text { S2(4,16); S3(4,15); S4(8,11,16); S5(3,4,8,18); S10(12,15); } \\
\text { S13(18); S15(13); S17(12); S20(4,11); S24(4); S25(17); S29(6) }\end{array}$ & 12 & 40 \\
\hline & 9 & $\mathrm{NU}$ & $\mathrm{MC}$ & $\begin{array}{c}\mathrm{S} 6(4,18) ; \mathrm{S} 11(3,4,11,18) ; \mathrm{S} 12(4) ; \mathrm{S} 14(19) ; \mathrm{S} 15(4) ; \\
\mathrm{S} 16(6,9,12,17,18,19) ; \mathrm{S} 17(20) ; \mathrm{S} 18(17,19) ; \mathrm{S} 21(1,2,4,8,19) \\
\mathrm{S} 22(15,18) ; \mathrm{S} 23(4,6) ; \mathrm{S} 24(1) ; \mathrm{S} 26(12) ; \mathrm{S} 28(3,12,19) \\
\mathrm{S} 29(13,18,19) ; \mathrm{S} 30(7)\end{array}$ & 16 & 53 \\
\hline & 10 & $\mathrm{PU}$ & $\mathrm{MC}$ & \begin{tabular}{|}
$\mathrm{S} 2(7,12,15) ; \mathrm{S} 3(8) ; \mathrm{S} 5(11) ; \mathrm{S} 8(7,9) ; \mathrm{S} 9(9) ; \mathrm{S} 10(6,14) ; \mathrm{S} 11(8,12) ;$ \\
$\mathrm{S} 15(7,8) ; \mathrm{S} 16(18) ; \mathrm{S} 19(1,4,13) ; \mathrm{S} 21(7,9,11,15) ; \mathrm{S} 22(19) ; \mathrm{S} 23(20) ;$ \\
$\mathrm{S} 25(16) ; \mathrm{S} 27(10) ; \mathrm{S} 28(11,14) ; \mathrm{S} 29(11,17)$
\end{tabular} & 17 & 57 \\
\hline & 11 & PU & NU & $\begin{array}{l}\mathrm{S} 2(18) ; \mathrm{S} 3(18) ; \mathrm{S} 5(12,20) ; \mathrm{S} 12(2) ; \mathrm{S} 13(2,15,19) ; \mathrm{S} 14(10) ; \mathrm{S} 16(3) ; \\
\text { S17(10,13); S18(1,2); S22(2,6,17); S24(11); S26(10,15); S27(9) }\end{array}$ & 13 & 43 \\
\hline & 12 & SU & PU & $\begin{array}{c}\text { S3(10); S8(2); S9(2); S10(1,5,19); S12(10); S13(11); S14(1); } \\
\text { S15(6); S17(7); S20(14); S24(19); S26(2); S27(1); S28(1); S30(2) }\end{array}$ & 15 & 50 \\
\hline & 13 & SU & $\mathrm{NU}$ & S4(12); S14(7) & 2 & 7 \\
\hline & 14 & SU & $\mathrm{MC}$ & 0 & 0 & 0 \\
\hline & 15 & PU & $\mathrm{NC}$ & S18(4) & 1 & 3 \\
\hline
\end{tabular}


Paper - Implementation of Interactive Conceptual Instruction (ICI) Learning Model Assisted by...

\begin{tabular}{|c|c|c|c|c|c|c|}
\hline $\begin{array}{l}\text { Changes } \\
\text { Category }\end{array}$ & No & $\begin{array}{c}\text { Pre- } \\
\text { test }\end{array}$ & $\begin{array}{c}\text { Post- } \\
\text { test }\end{array}$ & Student's Code (Question Number) & f & $\%$ \\
\hline & 16 & $\mathrm{MC}$ & $\mathrm{NC}$ & $\mathrm{S} 18(12)$ & 1 & 3 \\
\hline & 17 & $\mathrm{NC}$ & $\mathrm{MC}$ & $\mathrm{S} 30(13,20)$ & 1 & 3 \\
\hline & 18 & $\mathrm{NU}$ & $\mathrm{NC}$ & S18(13) & 1 & 3 \\
\hline & 19 & $\mathrm{NC}$ & $\mathrm{NU}$ & S18(6); S27(19) & 2 & 7 \\
\hline \multirow[t]{5}{*}{$\begin{array}{l}\text { No Change } \\
\text { (NCh) }\end{array}$} & 20 & PU & PU & $\begin{array}{c}\mathrm{S} 1(3,6,7,11) ; \mathrm{S} 2(5,8,11,20) ; \mathrm{S} 3(5,14) ; \mathrm{S} 4(7,13,15,17) ; \mathrm{S} 5(5,13) ; \\
\mathrm{S} 6(1,2,15,16,17,19) ; \mathrm{S} 7(1) ; \mathrm{S} 8(8) ; \mathrm{S} 9(4,13,16) ; \mathrm{S} 10(3,9,10,16,17) ; \\
\text { S11(14,15); S12(1,10); S13(9,10,14,20); S14(3,6,12,14,16); } \\
\text { S15(9,10,14); S16(13,14); S17(6,8,14,18); S18(7,8,9,10,14,18); } \\
\text { S19(9,10,14); S20(1,2,5,8,15); S21(6,10,16); S22(3,5,9); } \\
\text { S23(9,10,23,16,18); S24(9,16); S25(1,2,3,7,8,10,11,15); } \\
\text { S26(3,6,9,20); S27(5,6,7,14,15);S28(8,15); S29(8,9,10,15,16); } \\
\text { S30(3,8) }\end{array}$ & 30 & 100 \\
\hline & 21 & $\mathrm{NU}$ & $\mathrm{NU}$ & $\begin{array}{l}\text { S2(3,17); S3(3,16); S4(1,3); S14(4); S15(18,19,20); S16(15); } \\
\text { S17(9,15,19); S18(11); S19(12,18,19); S20(3,9,19); S26(7); } \\
\text { S27(2,3,11); S28(6,17); S29(3) }\end{array}$ & 14 & 47 \\
\hline & 22 & $\mathrm{MC}$ & MC & $\begin{array}{c}\text { S3(12); S7(4,6,16); S8(3,4,6,11,16,19); S9(6,8); S10(7); } \\
\text { S12(3,6,16,20); S13(4,12); S14(15,17); S16(4); S17(4); S20(7); } \\
\text { S21(18); S22(4,13); S24(15); S25(4,12); S26(1,4); S28(4,7,19); } \\
\text { S29(4); S30(6) }\end{array}$ & 19 & 63 \\
\hline & 23 & SU & SU & $\begin{aligned} \mathrm{S} 1(2) ; \mathrm{S} 3(2) ; \mathrm{S} 5(2) ; \mathrm{S} 7(13) ; \mathrm{S} 9(1) ; \mathrm{S} 11(1) ; \mathrm{S} 15(1) ; \mathrm{S} 16(1) ; \\
\mathrm{S} 17(3) ; \mathrm{S} 25(5) ; \mathrm{S} 26(5) ; \mathrm{S} 29(2)\end{aligned}$ & 12 & 40 \\
\hline & 24 & $\mathrm{NC}$ & $\mathrm{NC}$ & 0 & 0 & 0 \\
\hline
\end{tabular}

Information: S1-S30=Student 1 to Student 30; $\mathrm{MC}=$ Misconception; SU=Sounds Understanding; PU=Partial Understanding; $\mathrm{NU}=$ Not Understanding; $\mathrm{NC}=$ No Coding; $\mathrm{f}=$ frequency

Based on Table 4, 22 types of students' conceptual changes from 24 possible ones after participating in learning using Interactive Conceptual Instruction, assisted by computer simulations. Out of the seven types of conceptual changes in the Acceptable Change (AC) category, the types of change that the majority of students experience are the conversion of NU $\rightarrow$ SU and PU $\rightarrow$ SU. 77\% of the students experience the conceptual change in the AC category in each of these types of conceptions. An example of conceptual change of NU $\rightarrow$ SU is experienced by student 17 (S17) in answering Question 16 (Q16). Q16 is used to measure the students' conceptions of the effect of initial deviation on the spring period. S17 states that the spring period will be smaller when the spring deviation is enlarged during the pre-test. This is because of the more significant the initial deviation, the greater the period. The answer and reasoning are incorrect, and S17 answers with "not confident" can be categorized as not understanding the concept (NU). Then during the post-test, S17 states when the spring deviation is enlarged, the period cannot be determined. This is because the period of simple harmonic vibrations does not depend on its initial deviation. The answer is incorrect, while the reasoning is correct. Therefore, it can be categorized as partially understood (PU). In ICI learning, a conceptual change regarding the effect of initial deviation on spring is carried out by guiding students to explore and change the initial spring deviation in computer simulations and observing how it affects the size of the spring period. The students' observations are written in the PDEODE * E exploration sheet, used as a Research-Based Material in ICI learning. 
In comparison, the example of conceptual change of $\mathrm{PU} \rightarrow \mathrm{SU}$ is experienced by S14 in answering Q5 regarding the direction of the pendulum velocity. S14 states that he/she is not confident about the answer but is confident about the reasoning. During the pre-test, S14 states that when the pendulum is moving to the right, the direction of the velocity of the pendulum is to the left, contrary to the reasoning they give, which is the direction of the velocity of the simple harmonic vibration is similar to the direction of motion of the object. Thus, it is categorized as partially understood (PU). Then during the post-test, S14 states that the direction of the pendulum's velocity is to the right when the pendulum moves to the right and follows the trajectory of its motion. This is because simple harmonic vibration velocity is in the same direction as the object's motion. S14 is confident about his/her reasoning so that S14 is categorized as understanding the concept (SU). These students' conceptual changes are supported in the stages of ICI learning, especially at the Research-Based Material stage using computer simulations based on the characteristics of simple harmonic vibrations. In the simulation used, the direction of velocity at each point of the movement of the object is displayed with arrows, as shown in Figure 7, so that it is easier for the students to establish the direction of the pendulum's speed when it is moving in a simple harmonic motion.

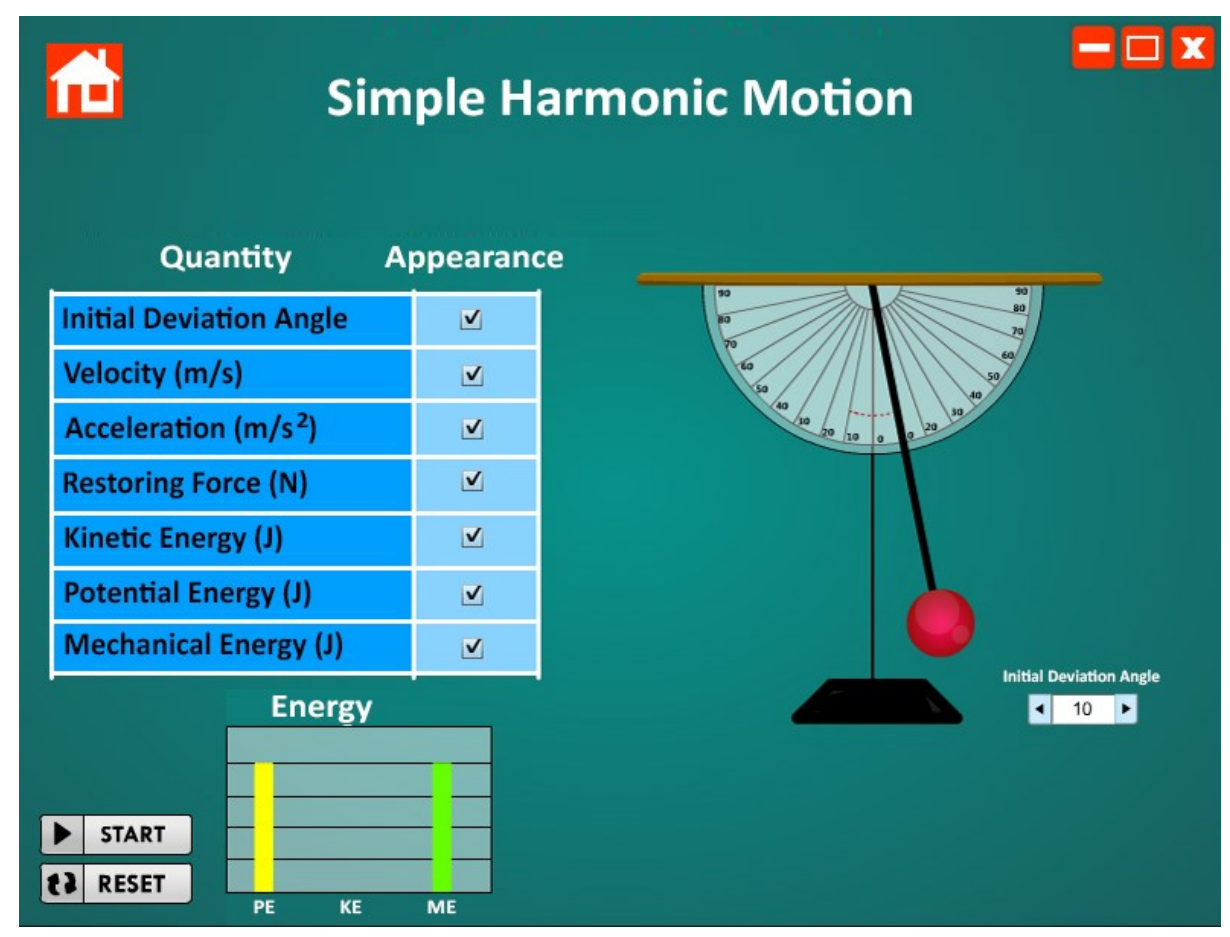

Fig. 7. The direction of velocity in simple harmonic vibration shown in computer simulation

Out of the 12 types of conceptual changes in the Not Acceptable (NA) category, the most common type experienced by students is the changing type of PU $\rightarrow$ MC. As many as $57 \%$ of students experience this type of change of conception. One of them is 
S27 when answering Question 10 (Q10) regarding the acceleration value of spring motion in various positions. Q10 is used to measure students' conceptions of the maximum and minimum values for the acceleration of simple harmonic vibrations. During the pre-test, S27 states that the correct statement regarding the acceleration of the block is $a o<a b(a o=$ acceleration in a balanced position; $a b=$ acceleration between the equilibrium position and the farthest deviation), S27's answer is correct, but S27 lacks confident about the answer. Their reasoning is that acceleration does not depend on the object's deviation. S27 is not sure of the sense, so it is categorized as partially understood (PU). Then during the post-test, S27 confidently answers and states that the acceleration of the block is $a o>a b$ with the consideration of the maximum acceleration when the object is at its equilibrium point. The reason and answer are incorrect, but if S27 states that they are confident, it can be categorized as a misconception (MC). The percentage of students who experience this type of change in conception is quite large. This shows that ICI learning assisted by computer simulations is not fully effective in changing students' conceptions of the Force and Vibration unit. This is due to several factors, one of which is the limitations of the researcher in controlling all research variables. For example, when participating in ICI learning assisted by computer simulations, several students fail to follow the lesson seriously. Thus, that students' conceptual change could not be optimally transformed to make their conceptions better.

Out of five types of conceptual change in the No Change (NCh) category, the type of conceptual change experienced by the majority of the students is the conversion of $\mathrm{PU} \rightarrow$ PU. As many as $100 \%$ of the remainder experienced this type of conversion. One of them is experienced by S10 in answering question number 9 (Q9), which contains a simple harmonic vibration acceleration graph. Q9 is used to measure the students' conceptions of the acceleration magnitude of simple harmonic vibrations on spring. During the pre-test, S10 confidently stated that the correct graph shows the magnitude of the object's acceleration when moving in a simple harmonic motion from Point $\mathrm{E}$ (farthest deviation) to return to Point $\mathrm{E}$ is Graph $\mathrm{C}$ with the reason that the maximum acceleration occurs when the object is at the farthest deviation point. As shown in Figure 8, the reason that S10 gives is correct. S10 was confident of their reasoning so that it was categorized as partially understood (PU). Then during the posttest, S10 stated that the correct graph showing the magnitude of the object's acceleration when moving in a simple harmonic motion from point $\mathrm{E}$ (farthest deviation) to return to point $\mathrm{E}$ is graph $\mathrm{A}$ with the reason that the maximum acceleration when the object is at the farthest deviation point. The reasoning that the S10 gave was correct. S10 was sure of their answer so that it was categorized as partially understood (PU). The S10's conception of simple harmonic vibrations acceleration had not changed even though they had followed several ICI lessons assisted by computer simulations. S10 remained at the partial conception (PU) level. From these findings, it can be said that ICI learning has not entirely changed students' conception for the better. The students persisted with their initial conception. Following previous findings, it is challenging to change conception because students tend to maintain the initial concept. This is supported by the statement from [12], which stated that changing students' conceptions takes a long time because of misconceptions embedded in the students' minds. Misconceptions have the 
following characters: challenging to change, stable, and well embedded in the cognitive realm of the students [42].

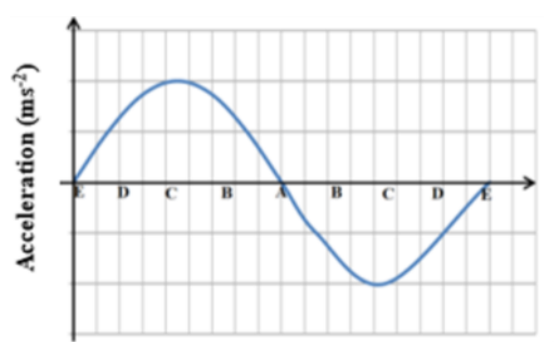

Graph C

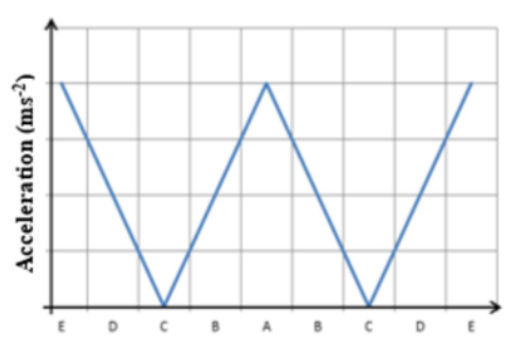

Graph A

Fig. 8. Students' answers regarding the Simple Harmonic Vibration acceleration graph

The changes in the NA and NCh concepts indicate that the implementation of ICI learning assisted by computer simulations cannot wholly change the students' conceptions of the Force and Vibration unit for the better. This can be caused by several factors, including the implementation of ICI learning assisted by computer simulations that are not yet perfect, or it could also be caused by factors from within the students themselves, such as the lack of motivation in learning Physics, the student's lack of familiarity in learning using computer simulations, students' dismissive attitudes in groups setting, students feeling uncomfortable with their groups, students not paying attention to teacher's directions and explanations during the learning process. This is supported by previous research [30] that explained the problem of researchers' limitations in controlling students' psychological aspects.

In general, the age of students' conceptual change categories after implementing Interactive Conceptual Instruction (ICI) learning is assisted by computer simulations. Furthermore, it suggests that the change in the AC (Acceptable Change) category is experienced by the majority of the students compared to other types of conceptual change, as shown in Figure 9.

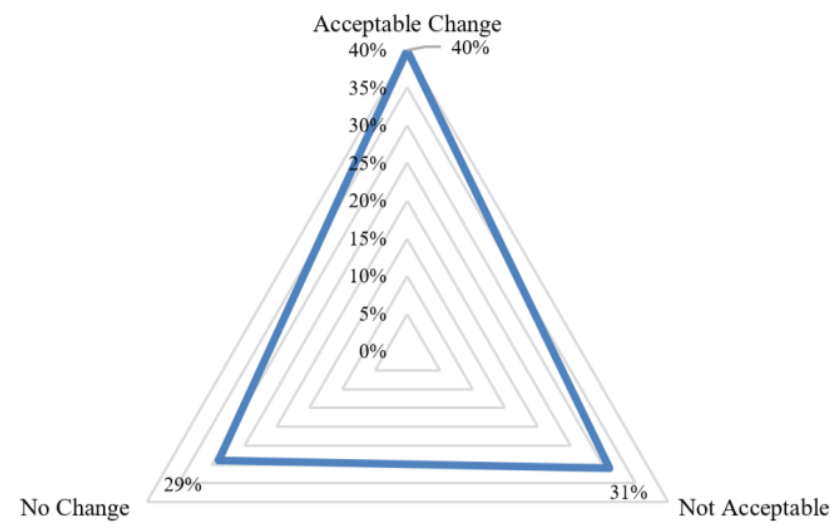

Fig. 9. Students' answers regarding the Simple Harmonic Vibration acceleration graph 
The changes in the student's misconceptions indicate that the type of change in their misconceptions regarding Force and Vibration tends to be positive. The category of conceptual changes is dominated by the Acceptable Change (AC) sub-category. The results obtained in this study are the following previously conducted research [9, 24, $25,30]$. Their findings indicated that the implementation of Interactive Conceptual Interaction could support conceptual change and reduce students' misconceptions. Backed by some of the results of previous research, it can be asserted that the implementation of Interactive Conceptual Instruction (ICI) learning effectively changes the students' conceptions of Force and Vibration for the better when assisted by computer simulations.

However, we specifically analyzed the section on changing the category of misconceptions. We observed that the changes in the pre-test for the variety of misconceptions are the information needed by practitioners in the field. The distribution of conception changes in the category of misconceptions is illustrated in Figure 10.

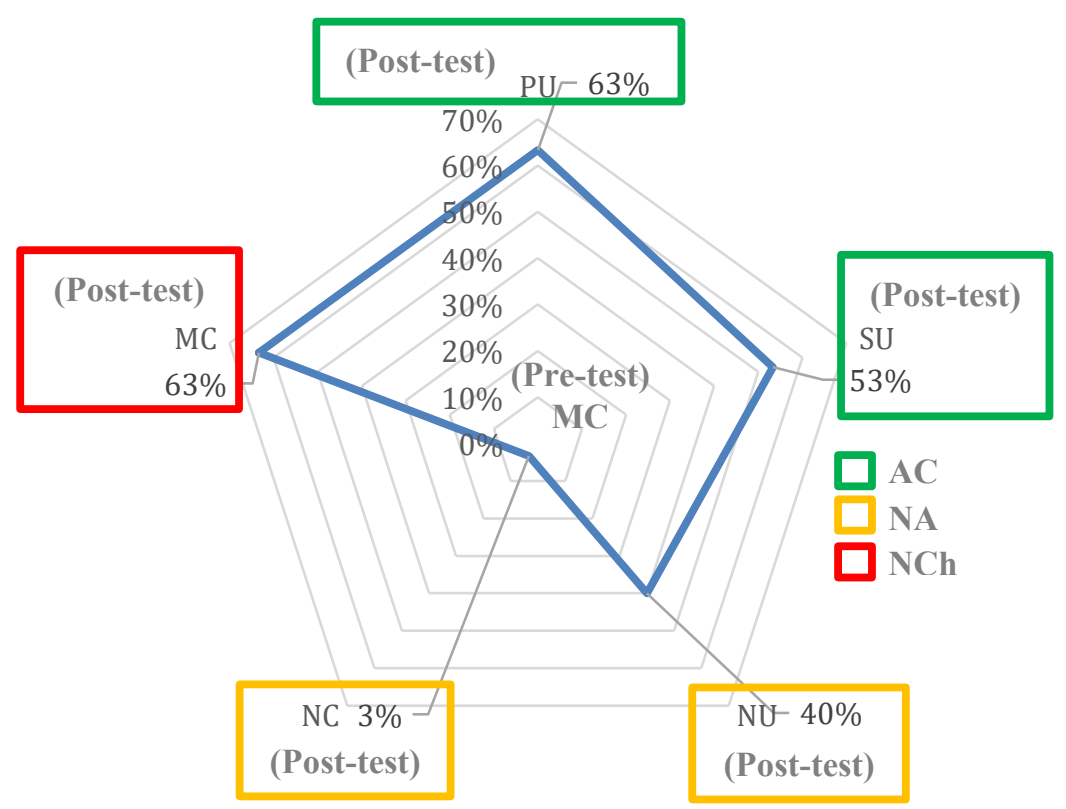

Fig. 10. Conceptual Change in the Misconception Category

Figure 10 shows that the changes identified from the misconception categories include: (1) Acceptable Change (AC) categories including MC-PU (63\%) and MC-SU (53\%) (Green Box); (2) Not Acceptable (NA) categories include MC-NU (40\%) and MC-NC (3\%) (Orange Box), and (3) No Change (NCh) category, namely MC -MC (63\%) (Red Box). The most significant changes occur in MC-PU (AC) and MC-MC (NCh). In contrast, minor changes occur in MC-NC (NA). This result is not distinctly different from Figure 9. The changes experienced in the category of misconceptions 
sequentially from the largest are AC, NCh, and NA. The ICI model assisted by computer simulations can change the students' understanding of their prior misconceptions because the AC category dominates the results obtained. In addition, we also received data on the students' misconceptions for the 20 four-tier questions used (Table 5).

Table 5. Categories of students' conceptual changes

\begin{tabular}{|c|c|}
\hline & Students' Misconception \\
\hline MC1 & The direction of restoring force is perpendicular to the object's deviation. \\
\hline MC2 & The restoring force possesses the same value at each point of the object's vibration. \\
\hline MC3 & $\begin{array}{l}\text { Simple harmonic vibration is the back-and-forth motion of an object around its equilibrium point } \\
\text { regardless of its amplitude. }\end{array}$ \\
\hline $\mathrm{MC4}$ & $\begin{array}{l}\text { Simple harmonic vibrations of a pendulum can occur to all initial deviation angles values. Both big } \\
\text { and small }\end{array}$ \\
\hline MC5 & The velocity direction of simple harmonic vibrations is opposite to the direct object's motion. \\
\hline MC6 & The velocity of the object at any point in simple harmonic vibrations is the same. \\
\hline MC7 & $\begin{array}{l}\text { The maximum speed of a simple harmonic vibration occurs at the maximum deviation and is zero } \\
\text { at the equilibrium point. }\end{array}$ \\
\hline MC8 & The acceleration's direction of simple harmonic vibrations is the same as the object's motion. \\
\hline MC9 & $\begin{array}{l}\text { The maximum acceleration of a simple harmonic vibration occurs at its equilibrium point and is } \\
\text { zero at the maximum deviation. }\end{array}$ \\
\hline $\mathrm{MC10}$ & The acceleration of the object at any point in simple harmonic vibrations is the same. \\
\hline MC11 & The period is the time taken to go through one incomplete vibration \\
\hline $\mathrm{MC12}$ & $\begin{array}{l}\text { The period of simple harmonic vibrations on a simple pendulum is affected by the initial angle of } \\
\text { deviation. }\end{array}$ \\
\hline $\mathrm{MC13}$ & $\begin{array}{l}\text { The mass of the pendulum influences the period of simple harmonic vibrations on a simple pendu- } \\
\text { lum. }\end{array}$ \\
\hline $\mathrm{MC14}$ & The length of the rope does not affect the period of the pendulum \\
\hline MC15 & Gravitational acceleration does not affect the period of the pendulum \\
\hline MC16 & $\begin{array}{l}\text { The initial deviation of the object influences the period of simple harmonic vibrations in the } \\
\text { spring-mass system. }\end{array}$ \\
\hline MC17 & $\begin{array}{l}\text { The period of simple harmonic vibrations in a spring-mass system is affected by gravitational ac- } \\
\text { celeration. }\end{array}$ \\
\hline MC18 & $\begin{array}{l}\text { The period of simple harmonic vibrations in a spring-mass system is directly proportional to the } \\
\text { spring constant and inversely proportional to the object's mass. }\end{array}$ \\
\hline MC19 & The total energy in simple harmonic vibrations is affected by the mass of the object. \\
\hline MC20 & $\begin{array}{l}\text { The maximum potential energy is at the equilibrium point, while the maximum kinetic energy is } \\
\text { the farthest deviation. }\end{array}$ \\
\hline \multicolumn{2}{|c|}{ MC1-MC20 = Misconceptions in question number } \\
\hline
\end{tabular}

In some parts, after the computer simulation-assisted ICI was applied, there are apparent changes in the students' conceptions, as shown in Figure 10. 


\section{Conclusion}

Based on the research results on implementing the Interactive Conceptual Instruction (ICI) learning model assisted by computer simulation, changes in students' conceptions are possible. These changes can steer them to further progress in a better direction. This is indicated by the changes in students' conceptions, sequentially from the most, namely the Acceptable Change (AC) categories (include MC-PU (63\%) and MC-SU (53\%), 2) No Change (NCh) type (MC - MC (63\%)), and Not Acceptable (NA) categories (include MC- NU (40\%) and MC-NC (3\%)). Then, the most significant changes occur in MC$\mathrm{PU}(\mathrm{AC})$ and MC-MC (NCh), while the minor change occurs in MC-NC (NA). Nevertheless, there are some limitations to these results as the simulation was only implemented in the classroom. Thus, it does not rule out the possibility that the simulation can also be used outside the classroom as material for the remediation of the misconceptions that occur. We hope that practitioners in the field can utilize this model to change students who have misconceptions about the concepts of force and vibration. In addition, it is possible that this research can be developed again to maximize the changes or reduce misconceptions that occur.

\section{Acknowledgment}

This work was financially supported by Penelitian Terapan Unggulan Perguruan Tinggi Research Grants, Ministry of Education, Culture, Research and Technology of the Republic of Indonesia in the fiscal year 2021.

\section{References}

[1] A. Aslan and G. Demircioğlu, "The Effect of Video-assisted Conceptual Change Texts on 12 th Grade Students' Alternative Conceptions: The Gas Concept," Procedia - Soc. Behav. Sci., vol. 116, pp. 3115-3119, 2014, https://doi.org/10.1016/j.sbspro.2014.01.718

[2] A. Shishigu, A. Hailu, and Z. Anibo, "Problem-based learning and conceptual understanding of college female students in physics," Eurasia J. Math. Sci. Technol. Educ., vol. 14, no. 1, pp. 145-154, 2018. https://doi.org/10.12973/ejmste/78035

[3] M. Farrokhnia, H. J. Pijeira-Díaz, O. Noroozi, and J. Hatami, "Computer-supported collaborative concept mapping: The effects of different instructional designs on conceptual understanding and knowledge co-construction," Comput. Educ., vol. 142, 2019. https://doi.org/10.1016/j.compedu.2019.103640

[4] M. Ainiyah, M. Ibrahim, and M. T. Hidayat, "The Profile of Student Misconceptions on the Human and Plant Transport Systems," in Journal of Physics: Conference Series, 2018, vol. 947, no. 1. https://doi.org/10.1088/1742-6596/947/1/012064

[5] I. Kaniawati, N. J. Fratiwi, A. Danawan, I. Suyana, A. Samsudin, and E. Suhendi, "Analyzing students' misconceptions about Newton's Laws through Four-Tier Newtonian Test (FTNT)," J. Turkish Sci. Educ., vol. 16, no. 1, pp. 110-122, 2019. https://doi.org/10. $\underline{1063 / 1.4983967}$

[6] N. N. Parwati and I. G. P. Suharta, "Effectiveness of the implementation of cognitive conflict strategy assisted by e-service learning to reduce students' mathematical misconceptions," 
Paper-Implementation of Interactive Conceptual Instruction (ICI) Learning Model Assisted by...

Int. J. Emerg. Technol. Learn., vol. 15, no. 11, pp. 102-118, 2020. https://doi.org/10.3991/ IJET.V15I11.11802

[7] N. J. Fratiwi, A. Samsudin, T. R. Ramalis, and B. Costu, "Changing students' conceptions of Newton's second law through express-refute-investigate-clarify (ERIC) text," Univers. J. Educ. Res., vol. 8, no. 6, pp. 2701-2709, 2020. https://doi.org/10.13189/ujer.2020.080655

[8] N. J. Fratiwi et al., "Developing memori on Newton's laws: For identifying students' mental models," Eur. J. Educ. Res., vol. 9, no. 2, pp. 699-708, 2020.

[9] R. Adimayuda, A. H. Aminudin, I. Kaniawati, E. Suhendi, and A. Samsudin, "A multitier open-ended momentum and impulse (MOMI) instrument: Developing and assessing quality of conception of 11th grade sundanese students with rasch analysis," Int. J. Sci. Technol. Res., vol. 9, no. 2, pp. 4799-4804, 2020. https://doi.org/10.17478/jegys.574524

[10] N. Hermita, A. Suhandi, E. Syaodih, A. Samsudin, Isjoni, and F. Rosa, “Assessing preservice elementary school teachers' alternative conceptions through a four-tier diagnostic test on magnetism concepts," Adv. Sci. Lett., vol. 23, no. 11, pp. 10910-10912, Nov. 2017. https://doi.org/10.1166/asl.2017.10184

[11] A. Zulfikar, D. Y. Girsang, D. Saepuzaman, and A. Samsudin, "Analyzing educational university students' conceptions through smartphone-based PDEODE*E tasks on magnetic field in several mediums," in AIP Conference Proceedings, 2017, vol. 1848. https://doi.org/ $\underline{10.1063 / 1.4983963}$

[12] A. Samsudin, A. Suhandi, D. Rusdiana, I. Kaniawati, and B. Coştu, "Promoting conceptual understanding on magnetic field concept through interactive conceptual instruction (ICI) with PDEODE*E tasks," Adv. Sci. Lett., vol. 23, no. 2, pp. 1205-1209, 2017. https://doi.org/ $\underline{10.1166 / \text { asl.2017.7539 }}$

[13] R. Leinonen, M. A. Asikainen, and P. E. Hirvonen, “Overcoming students' misconceptions concerning thermal physics with the aid of hints and peer interaction during a lecture course," Phys. Rev. Spec. Top. - Phys. Educ. Res., vol. 9, no. 2, 2013. https://doi.org/ $\underline{10.1103 / \text { physrevstper.9.020112 }}$

[14] E. Taslidere, "Development and use of a three-tier diagnostic test to assess high school students' misconceptions about the photoelectric effect," Res. Sci. Technol. Educ., vol. 34, no. 2, pp. 164-186, 2016. https://doi.org/10.1080/02635143.2015.1124409

[15] D. Kaltakci-Gurel, A. Eryilmaz, and L. C. McDermott, "Development and application of a four-tier test to assess pre-service physics teachers' misconceptions about geometrical optics," Res. Sci. Technol. Educ., vol. 35, no. 2, pp. 238-260, 2017. https://doi.org/10.1080/ $\underline{02635143.2017 .1310094}$

[16] I. Kaniawati et al., "An analysis of students' misconceptions about the implementation of active learning of optics and photonics approach assisted by computer simulation," Int. J. Emerg. Technol. Learn., vol. 15, no. 9, pp. 76-93, 2020. https://doi.org/10.3991/ijet . .v15i09.12217

[17] B. C. Madu, "Effect of the four-step learning cycle model on students' understanding of concepts related to simple harmonic motion," Asia-Pacific Forum Sci. Learn. Teach., vol. 13, no. 1, 2012.

[18] A. Samsudin et al., "Development of a multitier open-ended work and energy instrument (MOWEI) using Rasch analysis to identify students' misconceptions," Cypriot J. Educ. Sci., vol. 16, no. 1, pp. 16-31, 2021. https://doi.org/10.18844/cjes.v16i1.5504

[19] A. Samsudin et al., "Reconstructing Students ' Misconceptions on Work and Energy through the PDEODE * E Tasks with Think-Pair-Share," vol. 18, no. 1, pp. 118-144, 2021. https://doi.org/10.36681/tused.2021.56

[20] A. H. Aminudin, I. Kaniawati, E. Suhendi, A. Samsudin, B. Coştu, and R. Adimayuda, "Rasch Analysis of Multitier Open-ended Light-Wave Instrument (MOLWI): Developing 
and Assessing Second-Years Sundanese-Scholars Alternative Conceptions," J. Educ. Gift. Young Sci., vol. 7, no. 3, pp. 607-629, Sep. 2019. https://doi.org/10.17478/jegys.574524

[21] A. Samsudin, A. H. Aminudin, N. J. Fratiwi, R. Adimayuda, and M. N. Faizin, "Measuring students' conceptions of light waves: A survey in Central Java," in IOP Conference Series: Earth and Environmental Science, 2021, vol. 1796, no. 1. https://doi.org/10.1088/1742$\underline{6596 / 1796 / 1 / 012124}$

[22] S. Somroob and P. Wattanakasiwich, "Investigating student understanding of simple harmonic motion," in Journal of Physics: Conference Series, 2017, vol. 901, no. 1, https://doi.org/10.1088/1742-6596/901/1/012123

[23] L. S. Nadelson, B. C. Heddy, S. Jones, G. Taasoobshirazi, and M. Johnson, "Conceptual change in science teaching and learning: Introducing the dynamic model of conceptual change," Int. J. Educ. Psychol., vol. 7, no. 2, pp. 151-195, 2018, https://doi.org/10. 17583/ijep.2018.3349

[24] M. T. Chi, "Three types of conceptual change: Belief Revision, Mental Model transformation and Categorical shift," in Handbook of Conceptual change, 2008, pp. 61-82.

[25] A. Savinainen and P. Scott, "Using the force concept inventory to monitor student learning and to plan teaching," Phys. Educ., vol. 37, no. 1, pp. 53-58, 2002, https://doi.org/10.1088/ $\underline{0031-9120 / 37 / 1 / 307}$

[26] C. Tekkaya, "Remediating high school students' misconceptions concerning diffusion and osmosis through concept mapping and conceptual change text," Res. Sci. Technol. Educ., vol. 21, no. 1, pp. 5-16, 2003, https://doi.org/10.1080/02635140308340

[27] E. A. Patriot, A. Suhandi, and D. T. Chandra, "Effect of Implementation Interactive Conceptual Instruction with Multi Representation Approach To Improve Levels of Understanding on Work and Energy Subject Matter," 4th ICRIEMS Proc., pp. 21-28, 2016.

[28] H. Johan, A. Suhandi, A. R. Wulan, and S. Sipriyadi, "Impact of Learning Earth Litosphere using Interactive Conceptual Instruction on Logic Thinking, Conceptual Understanding, and Spiritual Aspect Embedding," J. Pendidik. Fis. Indones., vol. 14, no. 1, pp. 7-17, 2018, https://doi.org/10.15294/jpfi.v14i1.8259

[29] A. Samsudin, A. Suhandi, D. Rusdiana, and I. Kaniawati, "Preliminary Design of ICI-based Multimedia for Reconceptualizing Electric Conceptions at Universitas Pendidikan Indonesia," in Journal of Physics: Conference Series, 2016, vol. 739, no. 1, https://doi.org/ 10.1088/1742-6596/739/1/012006

[30] A. Samsudin, A. Suhandi, D. Rusdiana, I. Kaniawati, and B. Coştu, "Investigating the effectiveness of an active learning based-interactive conceptual instruction (ALBICI) on electric field concept," Asia-Pacific Forum Sci. Learn. Teach., vol. 17, no. 1, pp. 1-41, 2016. https://doi.org/10.1166/asl.2017.7539

[31] S. Poultsakis, S. Papadakis, M. Kalogiannakis, and S. Psycharis, "The management of Digital Learning Objects of Natural Sciences and Digital Experiment Simulation Tools by teachers," Adv. Mob. Learn. Educ. Res., vol. 1, no. 2, pp. 58-71, 2021. https://doi.org/ 10.25082/amler.2021.02.002

[32] S. Papadakis and M. Kalogiannakis, Mobile learning applications in early childhood education, vol. i. 2020.

[33] M. Ampartzaki, M. Kalogiannakis, and S. Papadakis, "Deepening our knowledge about sustainability education in the early years: Lessons from a water project," Educ. Sci., vol. 11, no. 6, 2021, https://doi.org/10.3390/educsci1 1060251

[34] S. Papadakis, "Advances in Mobile Learning Educational Research (A.M.L.E.R.): Mobile learning as an educational reform," Adv. Mob. Learn. Educ. Res., vol. 1, no. 1, pp. 1-4, 2021, https://doi.org/10.25082/amler.2021.01.001 
Paper-Implementation of Interactive Conceptual Instruction (ICI) Learning Model Assisted by...

[35] E. Fokides and D. Zachristou, "Teaching Natural Sciences to Kindergarten Students Using Tablets," vol. i, pp. 40-60, 2019, https://doi.org/10.4018/978-1-7998-1486-3.ch003

[36] S. Papadakis, "Evaluating a Teaching Intervention for Teaching STEM and Programming Concepts Through the Creation of a Weather-Forecast App for Smart Mobile Devices," 2020, pp. 31-53. https://doi.org/10.4018/978-1-7998-4576-8.ch002

[37] N. Vidakis, A. K. Barianos, A. M. Trampas, S. Papadakis, M. Kalogiannakis, and K. Vassilakis, "in-Game Raw Data Collection and Visualization in the Context of the 'ThimelEdu' Educational Game," in Communications in Computer and Information Science, 2020, vol. 1220, pp. 629-646, https://doi.org/10.1007/978-3-030-58459-7 30

[38] N. Srisawasdi and P. Sornkhatha, "The effect of simulation-based inquiry on students" conceptual learning and its potential applications in mobile learning," Int. J. Mob. Learn. Organ., vol. 8, no. 1, pp. 28-49, 2014, https://doi.org/10.1504/IJMLO.2014.059996

[39] P. Dorouka, S. Papadakis, and M. Kalogiannakis, "Nanotechnology and mobile learning: Perspectives and opportunities in young children's education," Int. J. Technol. Enhanc. Learn., vol. 13, no. 3, pp. 237-252, 2021, https://doi.org/10.1504/IJTEL.2021.115975

[40] M. Çalik, J. Ebenezer, T. Özsevgeç, Z. Küçük, and H. Artun, "Improving Science Student Teachers' Self-perceptions of Fluency with Innovative Technologies and Scientific Inquiry Abilities," J. Sci. Educ. Technol., vol. 24, no. 4, pp. 448-460, 2015, https://doi.org/10.1007/ $\underline{\text { s10956-014-9529-1 }}$

[41] M. Ceberio, J. M. Almudí, and Á. Franco, "Design and Application of Interactive Simulations in Problem-Solving in University-Level Physics Education," J. Sci. Educ. Technol., vol. 25, no. 4, pp. 590-609, 2016, https://doi.org/10.1007/s10956-016-9615-7

[42] M. Başer and Ö. Geban, "Effect of instruction based on conceptual change activities on students' understanding of static electricity concepts," Res. Sci. Technol. Educ., vol. 25, no. 2, pp. 243-267, 2007, https://doi.org/10.1080/02635140701250857

[43] N. Hermita et al., "The effectiveness of using virtual simulation and analogy in the conceptual change oriented-physics learning on direct current circuits," Turkish Online J. Educ. Technol., vol. 2017, no. December Special Issue INTE, pp. 347-356, 2017.

[44] G. Martínez, F. L. Naranjo, A. L. Pérez, M. I. Suero, and P. J. Pardo, "Comparative study of the effectiveness of three learning environments: Hyper-realistic virtual simulations, traditional schematic simulations and traditional laboratory," Phys. Rev. Spec. Top. - Phys. Educ. Res., vol. 7, no. 2, 2011, https://doi.org/10.1103/physrevstper.7.020111

[45] S. Rakic, N. Tasic, U. Marjanovic, S. Softic, E. Lüftenegger, and I. Turcin, "Student performance on an e-learning platform: Mixed method approach," Int. J. Emerg. Technol. Learn., vol. 15, no. 2, pp. 187-203, 2020, https://doi.org/10.3991/ijet.v15i02.11646

[46] J. W. Creswell, Research Design Qualitative, and Mixed Methods Approaches 4th ed. Thousand Oaks, California 91320: SAGE Publications Inc., 2014. https://doi.org/10.5539/ elt.v12n5p40

\section{$7 \quad$ Authors}

Ida Kaniawati is a senior lecturer at Departemen Pendidikan Fisika, Universitas Pendidikan Indonesia, Bandung, Indonesia. She received her Doctoral degree from Doctor Program of Science Education, Universitas Pendidikan Indonesia in 2009. Her current research interests are the development of learning models and media to minimize student misconceptions and STEM education. 
Paper-Implementation of Interactive Conceptual Instruction (ICI) Learning Model Assisted by...

Widyatami Nurul Maulidina is an undergraduate student at Departemen Pendidikan Fisika, Universitas Pendidikan Indonesia, Bandung, Indonesia. Her current research interests is the development of learning media to minimize student misconceptions.

Hera Novia is a lecturer at Departemen Pendidikan Fisika, Universitas Pendidikan Indonesia, Bandung, Indonesia. She received her Doctoral degree from Doctor Program of Science Education, Universitas Pendidikan Indonesia in 2018. Her current research interests are the development of learning models and media to minimize student misconceptions and metacognitive based learning.

Iyon Suyana is a senior lecturer at Departemen Pendidikan Fisika, Universitas Pendidikan Indonesia, Bandung, Indonesia. His current research interests is the development of learning models and media to minimize student misconceptions.

Achmad Samsudin is a lecturer at Departemen Pendidikan Fisika, Universitas Pendidikan Indonesia, Bandung, Indonesia. He received his Doctoral degree from Doctor Program of Science Education, Universitas Pendidikan Indonesia in 2016. His current research interests is the development of learning models and media to minimize student misconceptions.

Adam Hadiana Aminudin is a graduate student at Departemen Pendidikan Fisika, Universitas Pendidikan Indonesia, Bandung, Indonesia. His current research interests is the development of learning models and media to minimize student misconceptions.

Endi Suhendi is an associate professor at Departemen Pendidikan Fisika, Universitas Pendidikan Indonesia, Bandung, Indonesia. He received his Doctoral degree from Departmen Fisika, Institut Teknologi Bandung, Indonesia, in 2015. His current research interests are graphene-based nanoelectronic devices, sensors and educational technology.

Article submitted 2021-07-12. Resubmitted 2021-09-30. Final acceptance 2021-10-01. Final version published as submitted by the authors. 